\title{
QUALITY OF ARCHITECTURAL EDUCATION AT THE FACULTY OF ARCHITECTURE OF THE UNIVERSITY OF LJUBLJANA
}

\author{
Alenka Fikfak \\ Chair of Urbanism, Faculty of Architecture, University of Ljubljana, Zoisova 12, 1000 Ljubljana, Slovenia \\ E-mail: alenka.fikfak@fa.uni-li.si
}

Received 16 September 2013; accepted 02 December 2013

\begin{abstract}
The paper presents a study on the quality of architectural education at the Faculty of Architecture (FA) of the University of Ljubljana (UL) and the changes as a result of adopting the new rules, criteria and evaluation systems. In order to improve the quality of education at FA, we look at the indicators related to the data on student learning outcomes and the education as a whole. The formal data and the comparison of performance (quality) indicators between 2006 and 2012 are shown. Additionally, the basic scope of the Long-cycle Master's Study Programme in Architecture (MSPA) is presented in terms of content and mobility. The focus of architectural education at the UL FA, which includes practical, artistic and research work, and simulates work in the architectural studio, is on Design Studio course, which is directly complemented by the Architectural Workshop course. The work that includes both the individual approach and team work promotes connections among foreign and Slovenian students. Four cases in point are presented, confirming the significance of creative work within the courses of Design Studio, Architectural Workshop and Master Thesis.
\end{abstract}

Keywords: quality, design, design studio, architectural workshop, mobility, cooperation with the local community, Faculty of Architecture (FA) of the University of Ljubljana (UL), Slovenian Quality Assurance Agency for Higher Education (SQAA).

Reference to this paper should be made as follows: Fikfak, A. 2013. Quality of architectural education at the Faculty of Architecture of the University of Ljubljana, Journal of Architecture and Urbanism 37(4): 257-267.

\section{Introduction}

The focus of the study presented here is the quality of architectural education at the Faculty of Architecture (FA) of the University of Ljubljana (UL) and the changes occurring over the recent eight years as a result of adjusting to the new rules, criteria and study evaluation systems. The implementation of new study programmes, which were created as a consequence of the Bologna Declaration (1999), unfortunately closed off the Slovenian university space to the frames of individual faculties and thus kept the interdisciplinary ${ }^{1}$ studies at

\footnotetext{
1 From the Berlin Communiqué (2003): "Ministers are conscious of the need to promote closer links between the European Higher Education (EHEA) and the Research Area (ERA) in a Europe of Knowledge, and of the importance of research as an integral part of higher education across Europe /.../. The Ministers emphasise the importance of research and research training and the promotion of interdisciplinarity in maintaining and improving the quality of higher education and in enhancing the competitiveness of European higher education more generally."
}

a predominantly declarative level (Zavodnik Lamovšek, Foški 2012: 63). Similar to the term of interdisciplinarity whose contents reach into all fields of knowledge ${ }^{2}$, quality is assessed by the elements that are becoming normatively determined and which have almost no relation with the notion of 'quality'. According to the

\footnotetext{
2 "Exceptionally interdisciplinary content, which is such by its nature, is found in spatial management /.../. In this field of work, the paradigm of sustainable development is embedded in its concept, and for this reason it is one of the most suitable interdisciplinary study approaches /.../. The contents of sustainable development, spatial management and spatial planning are namely closely connected to the knowledge and skills of numerous fields and areas, which are more or less closely connected with space. The areas related to space, its characteristics and development, as the main interest, are spatial planning, architecture, landscape architecture, geography, geology, civil engineering (a structural engineer, a civil engineer, a municipal engineer, water management engineer ...) and geodesy." (Zavodnik Lamovšek, Foški 2012: 63).
} 
rules of the Slovenian Quality Assurance Agency for Higher Education (SQAA) "quality assurance in higher education means the entirety of policies, procedures and practices required for achieving, preserving and constant promotion of the development of quality in higher education system, higher education institutions and study programmes and higher vocational colleges" (Širok, Debevec 2013: 3). However, what is on paper easily understandable and clearly directed into promoting better and advanced study programmes is in practice, i.e. in the education process, causing many problems. Mainly, this is not because of the 'quality' of content - as the content is, in fact, left to the self-evaluation of the institution, i.e. to the faculty and its actors - but due to the rules of assessment, procedures ${ }^{3}$ of coordination, restrictions to flexible implementation and mobility, introduction of change and contemporary ideas that should be very responsive and adapted to modern times and society, while often, in practice, they die out or are replaced by new ones while the validation by relevant bodies is still on-going. The assessment of the quality of education at the Faculty of Architecture is time and again facing the problem that the existing criteria in higher education - which, generally, emphasize scientific and research work - are not necessarily suitable in architecture (Vodopivec, Gabrijelčič 2013: 4).

\section{Quality and education at the Faculty of Architecture of the University of Ljubljana}

At the UL FA, the improvement of quality is achieved using the mechanisms that are in line with Articles 3 and 4 of the Rules on the system of quality monitoring and assurance of the University of Ljubljana (2008) and the Rules on assessment and quality assurance at

\footnotetext{
3 Since the founding of SQAA, the first accreditation of a study programme formally takes 6-7 months after submitting a complete application. In practice, this means approximately 2 years after the initial preparations to formalize the format, i.e. from the moment when the content of the study programme is clear. According to a SQAA assessment, the extension of accreditation takes more than 8 months. In practice, if there are no special problems to be addressed, this takes 16 months. The procedure of confirmation of changes or amendments (minor changes, Criteria for accreditation ... SQAA 2010, Article 54) of a study programme until 2012 (obligatory confirmation at SQAA) took 6 months. Since 2012, the confirmation of minor changes has been the responsibility of the University, and the changes are communicated to the SQAA; thus, the procedures take about 2 months if there are no particularities). Significant changes are considered as a form of re-accreditation of the study programme. The syllabus for the next academic year is announced in May of each year. This means that in case of novelties of formal significance, the affirmation procedure of these changes should be finalised at the Faculty (Senate) no later than in March. This also means that the initial idea about "novelties" (if they formally do not surpass the framework of small changes) for the next academic year should be proposed one year in advance.
}

the University of Ljubljana (2000), which is achieved with the following activities: annual planning and reporting, annual self-evaluation ${ }^{4}$, accreditation of study programmes, training of teaching and professional staff for quality work, tutoring system, library information system, extracurricular activities, quality assurance of research work, transfer of knowledge into practice, survey among students, international cooperation, international connections, university awards and other awards etc. For improvement of quality of architectural education at the UL FA, we are looking at the indicators that are expressed as the data on student learning outcomes and the education as a whole (Table 1, selection of indicators).

Table 1 gives some formal data on the implementation of the relevant items and a comparison of performance (quality) indicators between 2006 and 2012 (the analyses look at the year of study, student generation and the entire study programme once each year within the self-evaluation report). The most relevant data were captured for the two periods, i.e. when the accreditation of the study programme in architecture was completed (Long-cycle Master's Study Programme in Architecture, MSPA; the data refer to undergraduate studies of architecture only) according to the Bologna system (in academic year 2005/2006), while in 2012 the re-accreditation process of the same study programme was launched (academic year 2011/2012). The comparison shows a gradual rise in almost all indicators. In the teaching process, the factor "integration with the environment" saw the greatest rise, which is, after all, very significant and encouraging for architectural education. Notably, this leap is the result of the activities of individual teachers and their volunteer work reaching beyond the normative framework of education (more on this in section 'Case examples showing a direct connection between creative, experiential work and interdisciplinarity'). In international activities and mobility, the number of incoming international students continues to grow, while the number of FA outbound students has levelled off. In relation to international activities, it should be noted that international research projects were most abundant in the two years that were

\footnotetext{
$4 \mathrm{UL}$ and its members have monitored their activities and analysed the efficiency of the studies for more than 30 years. After 2000 , quality assurance reports included educational and research activities, issues of organisation, basic work conditions, infrastructure, research and teaching staff, student activities, cooperation with users and international cooperation and, separately, they addressed the issue of quality assurance. In 2007, the Quality Assurance Commission of the UL proposed the merging of previously separate reports on quality and the annual (business) report. In its 2006-2009 strategy, UL set out the goal to connect the "quality system with the system of planning, reporting, awarding and management".
} 
Table 1. Quality and monitoring of basic indicators at the UL FA, comparison between academic years 2005/2006 and 2011/2012

\begin{tabular}{|c|c|c|c|}
\hline & academic year 2005/2006 & academic year 2011/2012 & notes: \\
\hline \multicolumn{4}{|c|}{1 TEACHING PROCESS IN UNDERGRADUATE PROGRAMMES - LONG-CYCLE MASTER'S PROGRAMME OF ARCHITECTURE } \\
\hline 1.1 Number of students & 928 full-time +44 part-time & 1105 full-time + 114 part-time & increase in enrolment \\
\hline 1.2 Proportion of foreign students enrolled & $2 \%$ & $2 \%$ & $\begin{array}{l}\text { proportion of enrolment places available for foreign students } \\
\text { remains the same, while demand continues to increase }\end{array}$ \\
\hline 1.3 Retention rate & $88 \%$ & $\begin{array}{l}90 \% \text {; retention from year } 4 \\
\text { to year } 5: 65 \%\end{array}$ & retention rate is high due to part-time students \\
\hline 1.4 Duration of studies & 8.72 years on average & 8.00 years & $\begin{array}{l}\text { full-time studies take } 5 \text { years ( } 10 \text { semesters) + additional } \\
\text { graduation year (Slovene: absolventski staž) }\end{array}$ \\
\hline 1.5 Number of graduates & 100 in University Studies & $\begin{array}{l}102 \text { in University Studies and } 54 \\
\text { in Long-cycle Master's Studies }\end{array}$ & data provided for calendar year (2011), not for academic year \\
\hline 1.6 Integration with the environment & $\begin{array}{l}\text { no data available, } 30 \text { different } \\
\text { activities estimated }\end{array}$ & more than 80 different activities & $\begin{array}{l}\text { workshops, competitions, projects, consultation sessions, } \\
\text { meetings, excursions, conferences, newsletters, journals ... }\end{array}$ \\
\hline \multicolumn{4}{|l|}{2 INTERNATIONAL ACTIVITIES and MOBILITY } \\
\hline 2.1 Agreements and contracts & 30 bilateral Erasmus agreements & 62 bilateral Erasmus agreements & \multirow{2}{*}{$\begin{array}{l}\text { despite the increase in agreements with foreign institutions, } \\
\text { the number of outbound FA students has levelled off }\end{array}$} \\
\hline 2.2 Outbound FA students & 41 & $46+6$ practice placement & \\
\hline 2.3 Incoming students to FA & 21 & 54 & $\begin{array}{l}\text { interest in completion of studies at FA (particularly from } \\
\text { SE European Countries) }\end{array}$ \\
\hline $\begin{array}{l}\text { 2.4 Proportion of teachers and researchers } \\
\text { in the Erasmus exchange programme }\end{array}$ & 7 & $\begin{array}{l}7+7 \text { guest teachers/researchers } \\
\text { at } F A\end{array}$ & $\begin{array}{l}\text { the number of guest teachers/researchers has increased due } \\
\text { to participation in other, non-formal types of cooperation }\end{array}$ \\
\hline 2.5 Courses held in a foreign language & $90 \%$ of the study programme & $90 \%$ of the study programme & $\begin{array}{l}\text { the EMŠ in Architecture has been accredited as a Slovenian } \\
\text { programme }\end{array}$ \\
\hline \multicolumn{4}{|l|}{3 HUMAN RESOURCES } \\
\hline 3.1 Changes in indicators of human resources & no changes & 9 retirements, 3 new teachers & retirement scheme according to ZUJF \\
\hline $\begin{array}{l}\text { 3.2 Average evaluation of teachers in } \\
\text { student surveys }\end{array}$ & no data available & +2.3 (evaluation from -3 to +3 ) & $\begin{array}{l}\text { changed assessment scale; survey results are not publicly } \\
\text { available }\end{array}$ \\
\hline 3.3 Promotions & 4 & 12 & data by calendar year $(2006,2012)$, not by academic year \\
\hline $\begin{array}{l}\text { 3.4 Proportion of teaching performed } \\
\text { by practising professionals }\end{array}$ & no data available & $6.6 \%$ & inclusion of the industry/economy into the teaching process \\
\hline \multicolumn{4}{|l|}{4 RESEARCH } \\
\hline $\begin{array}{l}4.1 \text { Number of international } \\
\text { research projects }\end{array}$ & 6 & 8 & $\begin{array}{l}\text { ties with enterprises and other institutions; contact with } \\
\text { advancement of innovations }\end{array}$ \\
\hline $\begin{array}{l}\text { 4.2 Number of scientific papers } \\
\text { in registered databases }\end{array}$ & 52 in Slovenia and 6 abroad & 53 in Slovenia and 19 abroad & connection of practice and research \\
\hline $\begin{array}{l}\text { 4.3 Number of scientific monographs } \\
\text { per teacher or scientist }\end{array}$ & $\begin{array}{l}9 \text { in Slovene, } 1 \text { in a foreign } \\
\text { language }\end{array}$ & $\begin{array}{l}3 \text { in Slovene, } 1 \text { in a foreign } \\
\text { language }\end{array}$ & younger staff who are introduced into research work \\
\hline \multicolumn{4}{|l|}{5 LIBRARY AND PUBLISHING ACTIVITIES } \\
\hline 5.1 Total number of library users & 1,649 active members & 1,700 active members & $\begin{array}{l}\text { after the completion of studies, library membership } \\
\text { is no longer active }\end{array}$ \\
\hline 5.2 Common library stock & 20,091 items & 20,615 items & continuous additions of new stock \\
\hline 5.3 Interlibrary loan service & \begin{tabular}{|l}
81 items of library stock \\
forwarded
\end{tabular} & $\begin{array}{l}53 \text { items of library stock } \\
\text { forwarded }\end{array}$ & - \\
\hline 5.4 Management of bibliographies & $\begin{array}{l}413 \text { entries to the COBISS } \\
\text { database }\end{array}$ & $\begin{array}{l}812 \text { entries to the COBISS } \\
\text { database }\end{array}$ & monographs, papers, conference articles and executed works \\
\hline 5.5 Publishing activities & no data available & 28 new publications & encouragement of electronic publishing \\
\hline \multicolumn{4}{|l|}{6 INFORMATION SYSTEM } \\
\hline 6.1 FA website & $\begin{array}{l}\text { complete redesign } \\
\text { of the website in } 2005\end{array}$ & start of FA website redesign & $\begin{array}{l}\text { redesign of the shape, image and way of operation as } \\
\text { a web office; first FA website created in } 1998\end{array}$ \\
\hline 6.2 Moodle virtual classroom & web-hosting at FGG & $\begin{array}{l}\text { independent classroom on the } \\
\text { FA server }\end{array}$ & $\begin{array}{l}\text { support to the educational process and record keeping: } \\
\text { ŠIS - electronic student's transcript (Slovene: indeks) }\end{array}$ \\
\hline $\begin{array}{l}\text { 6.3 Business and human resources } \\
\text { information management }\end{array}$ & operation of relevant systems & operation of relevant systems & continuous upgrading of systems \\
\hline 6.4 Connectivity of information systems & no connections & $\begin{array}{l}\text { direct exchange between FRS, } \\
\text { ŠR and the library }\end{array}$ & continuous upgrading of systems \\
\hline \multicolumn{4}{|l|}{7 STUDENT SERVICES } \\
\hline 7.1 Tutoring & student/tutor coordinator & teacher (tutor) coordinator & reorganised tutoring \\
\hline 7.2 Student board & no data available & 10 council members & - \\
\hline 7.3 Extra-curricular activities & excursions, visits, workshops & excursions, visits, workshops & $\begin{array}{l}\text { continuous increase of activities; a week of field exercises } \\
\text { and excursions }\end{array}$ \\
\hline 7.4 Presence in FA organisation bodies & $\begin{array}{l}\text { in } 70 \% \text { of FA management } \\
\text { bodies }\end{array}$ & in all FA management bodies & $\begin{array}{l}\text { in the Senate, UO, Quality Committee, KŠZ and other work } \\
\text { bodies }\end{array}$ \\
\hline 7.5 Status of students with a disability & no data available & 5 students & $\begin{array}{l}\text { adjustments during lectures and exercises and/or the way } \\
\text { of testing and assessment }\end{array}$ \\
\hline \multicolumn{2}{|l|}{$\begin{array}{l}\text { FA - Faculty of Architecture } \\
\text { FGG - Faculty of Civil and Geodetic Engineering } \\
\text { EMŠ - Long-cycle Master's Study Programme }(5+0) \\
\text { COBISS - Slovene Co-operative Online Bibliographic s }\end{array}$} & \multicolumn{2}{|l|}{$\begin{array}{l}\text { UO - Management Board } \\
\text { KŠZ - Academic Affairs Commission } \\
\text { ŠIS - Student Information System } \\
\text { ZUJF - Fiscal Balance Act }\end{array}$} \\
\hline
\end{tabular}

ŠR - Student Affairs Office

Note: in 2005/2006 some data were not yet monitored, while other data were not publicly available due to data protection, but were already being compiled, e.g. student surveys; depending on the indicator, some data were captured for the calendar year, not the academic year; most data are after Bonča et al. (2012), Vodopivec, Gabrijelčič (2013). 
selected for comparison. As can be seen, the indicator of "Research" is the weakest link in the operation of the UL FA. The indicators of "Human resources" show considerable changes that were introduced at FA in 2012 and are related to the "lowering of the average age of staff". "Library and publishing activities" and "Information system" confirm the good support and stability of the modern-day adjustments to the environment and educational needs. The indicator "Student services" shows how the students are becoming a part of the faculty, helping to create its image and impact the changes and improvements of the study programme.

In the framework of its education, the UL FA has a clear vision of implementation and pursuit of quality, which is reflected in the achievements that the FA will continue to pursue in the future:

- Shortening the length of the studies (to prevent the students to lose contact with the faculty, study process and mentor/tutor) - as indicated by indicator 1.4 in Table 1.

- Additional education for architects (advanced education and an informal type of life-long learning) and connection with the studies - as indicated by indicator 1.6 in Table 1.

- Additional lectures of renowned architects (guest lectures, project presentations by project designers; field visits of new executed projects) - as indicated by indicators 1.6, 2.4 and 2.5 in Table 1.

The aforementioned achievements to be followed are best expressed in the following activities of architectural education, which have the most impact on the quality in the sense of learning to do "good architecture":

- final student exhibitions as part of Design Studio (overview of work in the course with different teachers and comparison of results),

- building of a school in the South African Republic (international recognisability of FA),

- establishment of a permanent constructive dialogue between teachers and students (continuation of student roundtables),

- successful connection with practice, each year supported by more than 20 successful urban planning and architectural workshops,

- student exchange at UL through elective courses (connecting the content of different professions among students),

- FA educators are successful professionally; they are continuously winning competition awards, and professional domestic and international awards. They also work as reviewers or board members for distinguished professional international awards in many European countries,
- student mobility within the Project Design course (mix of different forms of work and creation, critical assessment of foreign students),

- engagement of students in different international activities (comparison of study programme quality through student activities in different international competitions, workshops etc.),

- interest in, and applications to, Erasmus student placements (increase of student activities in the international environment in practice),

- one of the most important novelties is the tendency to connect the content of different courses during exercises. This is reflected in the form of a comprehensive approach and inclusion of interdisciplinary content where all knowledge is combined in a fullyear project in the Design Studio course.

\section{The educational focus of MSPA}

In Slovenia, MSPA offers a relevant format of a multi-disciplinary educational approach in the field of architecture, connecting the fields of technical engineering, and design and art. Hence, it represents a good starting point for development of the profession and, as a result, an efficient solving of specific problems in the practice. Unfortunately, the Bologna reform closed off the Slovenian higher education to the domain of individual faculties, and thus kept the interdisciplinary approach to the studies at a predominantly declarative level; indeed, MSPA (Table 2) could suffer a similar fate. However, the system of studies at FA has been designed in a way to enable the connectivity with other institutions and study programmes, i.e. with the delivery of upgraded study courses (and elective courses) and through student and teacher mobility. Importantly, the changes have not remained at the declarative level - efficient formats of interdisciplinary ${ }^{5}$ learning have been implemented, which are particularly evident in Design Studio in Architectural Workshop courses.

The focus of training in architectural education at the FA, which includes practical, artistic and research work, and simulates work in the architectural studio,

\footnotetext{
5 The principles of interdisciplinarity are introduced through the following forms of work (Ivanitskaya et al. 2002; cf.: Marentič Požarnik 2010): Student group work, especially co-operative learning; Interactive classes which include dialogue, discussions and debates; Discussions in form of 'for and against', "brainstorming" and "aquarium"; Project study work; Role-play and simulation; Participative games; Indirect experience with active visits to different areas and spaces (also Richardson, Friend 2006); Conducting studies in connection with different environment and social groups (neighbours, local community, businesses, various associations and organisations etc.) and in connection with the faculties of other graduate schools (even internationally); Use of the information communication technology (ICT).
} 
Table 2. Changes in education of architecture at UL FA and the key elements of the study programme

\begin{tabular}{|c|c|c|c|c|c|c|c|c|}
\hline $\begin{array}{l}\text { title of study } \\
\text { programme }\end{array}$ & $\begin{array}{l}\text { year of } \\
\text { implementation }\end{array}$ & $\begin{array}{l}\text { formal } \\
\text { structure }\end{array}$ & $\begin{array}{l}\text { content } \\
\text { structure }\end{array}$ & $\begin{array}{l}\text { introduction } \\
\text { of novelties }\end{array}$ & $\begin{array}{l}\text { non-formal novelty } \\
\text { elements }\end{array}$ & $\begin{array}{l}\text { key study } \\
\text { courses }\end{array}$ & $\begin{array}{l}\text { study } \\
\text { practical } \\
\text { training }\end{array}$ & mobility \\
\hline $\begin{array}{l}\text { University } \\
\text { Study } \\
\text { Programme } \\
\text { in Architecture }\end{array}$ & $\begin{array}{l}\text { amendments } \\
\text { in } 1989\end{array}$ & $\begin{array}{l}4,5 \text { years; } \\
\text { compulsory } \\
\text { contents: } 180 \\
\text { ECTS, } 67 \% \\
\text { elective } \\
\text { contents: } \\
90 \text { ECTS, 33\% }\end{array}$ & $\begin{array}{l}\text { osnove: } \\
\text { 1.-4. semester } \\
\text { poglobitev: } \\
\text { 5.-9. semester } \\
\text { zaključno delo: } \\
\text { absolvent }\end{array}$ & $\begin{array}{l}\text { concentrations } \\
\text { (majors) in year } \\
\text { 4: architecture, } \\
\text { urban planning, } \\
\text { design }\end{array}$ & $\begin{array}{l}\text { within the course } \\
\text { of Design and } \\
\text { Composition } 4 \\
\text { (all concentrations) } \\
\text { elaboration } \\
\text { of architecture } \\
\text { design projects }\end{array}$ & $\begin{array}{l}\text { Design and } \\
\text { Composition } \\
(1,2,3,4,5) \\
\text { and graduation } \\
\text { work }\end{array}$ & & $\begin{array}{l}\text { mobility was not so } \\
\text { usual; increase of it } \\
\text { from the year } 2000 ; \\
\text { mobility bettwen } \\
\text { faculties of UL } \\
\text { as a part of study } \\
\text { programmes was } \\
\text { not part of rules }\end{array}$ \\
\hline $\begin{array}{l}\text { Long-cycle } \\
\text { Master's Study } \\
\text { Programme } \\
\text { in Architecture }\end{array}$ & $\begin{array}{l}\text { initial } \\
\text { accreditation in } \\
2006 \text { (academic } \\
\text { year } 2005 / 2006 \text { ) }\end{array}$ & $\begin{array}{l}300 \text { ECTS; } 5 \\
\text { years; } \\
\text { compulsory } \\
\text { contents: } \\
224 \text { ECTS, } 75 \% \\
\text { elective } \\
\text { contents: } \\
76 \text { ECTS, } 25 \%\end{array}$ & $\begin{array}{l}\text { osnove: } \\
\text { 1.-4. semester } \\
\text { poglobitev: } \\
\text { 4.-9. semester } \\
\text { zaključno delo: } \\
\text { 10. semester }\end{array}$ & $\begin{array}{l}\text { courses } \\
\text { Architectural } \\
\text { Workshop 1, } 2 \\
\text { and 3 }\end{array}$ & $\begin{array}{l}\text { introduction } \\
\text { of many elective } \\
\text { courses }\end{array}$ & $\begin{array}{l}\text { Design Studio } \\
(1,2,3,4,5) \text {, } \\
\text { Architectural } \\
\text { Workshop } \\
(1,2,3) \text {, } \\
\text { Master's Thesis }\end{array}$ & 8 ECTS - 3\% & $\begin{array}{l}\text { student can a semester } \\
\text { (max 2) } \\
\text { of study transferfrom } \\
\text { any of the programmes } \\
\text { from the fields of } \\
\text { architecture; mobility } \\
\text { is also required } \\
\text { according to the rules } \\
\text { of UL - } 5 \% \text { of elective } \\
\text { subjects from different } \\
\text { faculty }\end{array}$ \\
\hline $\begin{array}{l}\text { Long-cycle } \\
\text { Master's Study } \\
\text { Programme } \\
\text { in Architecture }\end{array}$ & $\begin{array}{l}\text { entry record } \\
\text { (for SQAA) in } \\
\text { April } 2012\end{array}$ & no changes & no changes & - & $\begin{array}{l}\text { commission } \\
\text { assessments } \\
\text { of courses and } \\
\text { projects in Design } \\
\text { Studio; new } \\
\text { work groups, } \\
\text { connections with } \\
\text { the industry }\end{array}$ & no changes & no changes & no changes \\
\hline $\begin{array}{l}\text { Long-cycle } \\
\text { Master's Study } \\
\text { Programme } \\
\text { in Architecture }\end{array}$ & $\begin{array}{l}\text { extension of } \\
\text { accreditation } \\
\text { in June } 2013 \\
\text { (since April 2012) }\end{array}$ & no changes & no changes & - & no changes & no changes & no changes & no changes \\
\hline
\end{tabular}

Notes: Formally, the programme is similar to the one before the Bologna reform, i.e. no major formal changes have been introduced in the last 8 years due to the accreditation process (major changes are not allowed; SQAA, Article 54, Rules for accreditation and external evaluation of higher education institutions and study programs). Basically because the MSPA at FA is still organized as a unified programme $(5+0)$.

is the Design Studio course (in study years 1-5). The work in the Design Studio course is highly influenced by the work outside school, i.e. professional and extracurricular, which builds a young person's point-ofview: field work, site visits, seminar excursions, visits of architecture projects, visits and cooperation in exhibitions, roundtables, professional meetings etc. The Design Studio course in the different study years is directly complemented by Architectural Workshop 1, 2 and 3 , where the individual mentors typically arrange, directly with a potential client, a several-day visit at a site and field work. Next to the teaching process on the FA premises, the cooperation with local communities in the form of living and field experience and direct contact with inhabitants is important. The "local" mobility goes hand in hand with the mobility of foreign students, as all current Erasmus exchange students at the FA are included into this type of work.

\section{Design Studio}

The Design Studio course, commonly referred to as the "Seminar", represents the backbone, i.e. the realisation of architectural studies. Within the seminar, the students who are assisted by the mentor and as- sistants, technical collaborators and invited professionals get to know the principles and procedures of design, and project approach to planning and designing architecture and urban design. Using a methodological approach, they learn how to overcome the fear of the blank page, where to start and how to complete a task, how to identify and define problems and how to solve these problems using theoretical and practical knowledge.

In working on a real project, the student deals with architectural, functional, technical, environmental, social and other issues of building. The subject is adapted to practical challenges and needs, thus substituting routine academic work with emergent new, vital and timely forms that are responsive to social and spatial issues. In the final project the student learns how to integrate essential building properties, such as mechanical resilience and stability, safeguarding hygiene and health, safety and energy preservation ${ }^{6}$. During

6 The elements are in compliance with the principles of Construction Products Regulation (EU) No 305/2011 (CPR) which repeals the Construction Products Directive (EU) No 89/106/EEC (CPD). 
the studies, the student work in the Design Studio course evolves with increasingly growing demands, and is upgraded and finalised in the Master Thesis. The Master Thesis includes the subject matters that help the student to reach the goals and competences of architectural studies: the theoretical and practical aspects of urban planning and design, mastering methods of planning and knowledge of basic legal aspects of spatial management, the basics of action planning and strategic evaluation, the basics of communal and housing economy, and an in-depth knowledge of the operation of the public sector, from the government level to local communities to corporate public services, knowledge and mastering of urban design techniques, planning and design, and knowledge of basic project management and quality control.

\section{Architectural Workshop}

At the UL FA, student urban design and architectural workshops have had a tradition of more than 40 years. First, the workshops were organised in the framework of study seminars at the local level with individual teachers at the Ljubljana School of Architecture. Already in the early 1980s, Professor Edo Ravnikar organised the first five international workshops in cooperation with the architecture schools in Trieste, Graz and Vienna (Gabrijelčič 2010). Organised by the UL FA, several hundred domestic and foreign students and many teachers from mostly western countries participated in these first international workshops. For the first time in Slovenia, next to the learning opportunity, the students had the opportunity to address real spatial problems and were offered the possibility of international exchange and comparison. Based on these positive experiences, the Slovenian ministry responsible for the environment and spatial planning paid great attention to these workshops.

Within the study programme, the students are each year included in different urban design and architectural workshops. Importantly, students of different years and study programmes (architecture, urban design, spatial planning, landscape architecture etc.) are included in the work and education. In this way, the work by the students of architecture is enriched by knowledge from other fields. The student workshops address real professional questions, set up dialogue between professions, expand contacts among domestic and foreign universities, transfer the knowledge of foreign experts to the domestic professional environment and, last but not least, establish durable professional and personal ties and, on this basis, shape a common cultural awareness about the meaning of a planned environment (Gabrijelčič 2010: 151). As a result of the many actions involving workshops, in 2012 the ULFA published a scientific monograph (Gabrijelčič, Fikfak 2012). Starting in 2013, based on the success of the monograph, the first issue of a new journal "Creativity game (CG) - Theory and Practice of Spatial Planning" will be published, representing the results of professional work, teaching and scientific research, which, by using creativity and abstract thinking, culminate in a continuous flow of experiential learning about spatial values and the related processes.

\section{Mobility and Erasmus exchange}

Within the Erasmus Programme, the UL FA has signed several agreements with universities abroad, and the number continues to grow. Within the capacity of FA operations and workload of teachers, we strive to give opportunity to anyone who wants to obtain architectural knowledge at our institution, and no candidate is rejected. In 2011/2012, there were 54 foreign students (see Table 1), and in 2012/2013 the following applied: winter semester: 64 students taking the Design Studio course, mostly study years 3 and 4; the Erasmus students cannot enrol in the Design Studio course in the summer semester, as this is a full-year course, except in year 5 . We feel that with the current number of foreign students sustainability can still be kept; however, due to the specifics of working with foreign students, an uncontrolled increase in the number of foreign students could negatively affect the quality of the study process.

The nature of the Design Studio course enables an overlap with the work within the so-called seminars, along with a comparison of domestic and foreign work methods and exchange/confirmation of international experience. Each year, several guest teachers are included into the teaching process, while there are three foreign citizens on UL FA permanent staff.

The work, using both an individual approach and team work, encourages connections between foreign and Slovenian students, while at the same time this enables an organised exchange of information between students who have had experience with the exchange and those who are thinking about taking part. The exchange is realised through exhibitions and lectures given by students.

\section{Case examples showing a direct connection between creative, experiential work and interdisciplinarity}

In the continuation, four different cases are presented which confirm the significance of creative work within the courses Design Studio, Architectural Workshop and Master Thesis. The content of the course is important, but equally so the commitment of the lecturer 
and how the course is taught. This is best illustrated on the case of building a school in the South African Republic (section 'Building a school in the South African Republic'), which doubtlessly goes beyond the education format prescribed in curricula and accreditation forms and norms; however, this type of work is necessary for constant advancement of education and knowledge in architecture and, most importantly, for continuous improvement of the quality of content of architectural education.

\section{Building a school in the South African Republic}

In 2010, the UL FA joined the international network for the construction of educational buildings in developing countries, initiated by the Austrian $\mathrm{SARCH}^{7}$ foundation. Within the network, the students from various European schools of architecture - TU Wien, TU Graz, Kunstuni Linz, FH Kärnten, RWTH Aachen and TU München - have in the past decade designed and, together with the local population, built several school buildings and kindergartens in different parts of the South African Republic (http://www.saip.si/; see Fig. 1).

In autumn 2010, the students and mentors of the UL FA built a library with a classroom in the school complex Ithuba Skills College (school which places emphasis on teaching manual skills, founded by SARCH in 2006). The school is located outside the Magagula Heights Township, a poor shantytown for black population south of Johannesburg (Vodopivec et al. 2011). 20 senior students participated in the project, led by four mentors, over a period of the full academic year. In the first semester the students got to know the country, its history, culture, art and geographic, economic and social features, while in the second semester the focus was on project preparation, practical workshops and collection of funds for construction and the building itself. In mere eight weeks, the students and the local population built the building from foundation to the roof, including all equipment. The concept of the construction is an attempt of a contemporary interpretation of the traditional way of construction in Africa, with walls made of clay and straw. The team of mentors who supervised the work and execution of the projects is as

\footnotetext{
"In 2003, Christoph Chorherr, an environmental economist, politician and long-standing spokesperson of the Green Party in the Austrian State Council, founded the SARCH foundation (Social Sustainable Architecture), supported by the City of Vienna, aiding socially disadvantaged groups in South Africa. Many Schools of Architecture from Austria, Switzerland and Germany decided to participate. Under mentor supervision and in cooperation with local inhabitants, the students from the architecture schools have in recent years built several buildings for children, i.e. kindergartens, school classrooms, centres for disabled children etc. in the poor shantytowns (so-called townships) in the suburbs outside Johannesburg" (http://www.saip.si/).
}

follows: Prof. Aleš Vodopivec, Ph.D, Assocc. Prof. Tadej Glažar, MSc, Assist. Prof. Anja Planišček, MSc, and Assist. Josip Konstantinovič. A similar principle of preparation, planning, work and on-site construction was used when building a multi-purpose hall (2011).

Case of the international architectural and urban design workshop "Visions, scenarios and concept of spatial development of the Šmartinska Street corridor, with an emphasis on transport and architectural design of the Šmartinska Street as a city boulevard", 2006

During the construction of the Ljubljana northern by-pass and East motorway, great development opportunities emerged in East Ljubljana. However, the Ljubljana City Administration had no proper spatial development vision or policy in place that would help direct individual interests and activities. During the urban planning and architectural workshop, an opportunity arose to connect theoretical and practical knowledge of different professions (also with the help of participants from abroad) on the real case of making a sample project of a new city boulevard. This was also an opportunity for experts from different institutions to practically test or illustrate their working hypotheses (Gabrijelčič 2010).
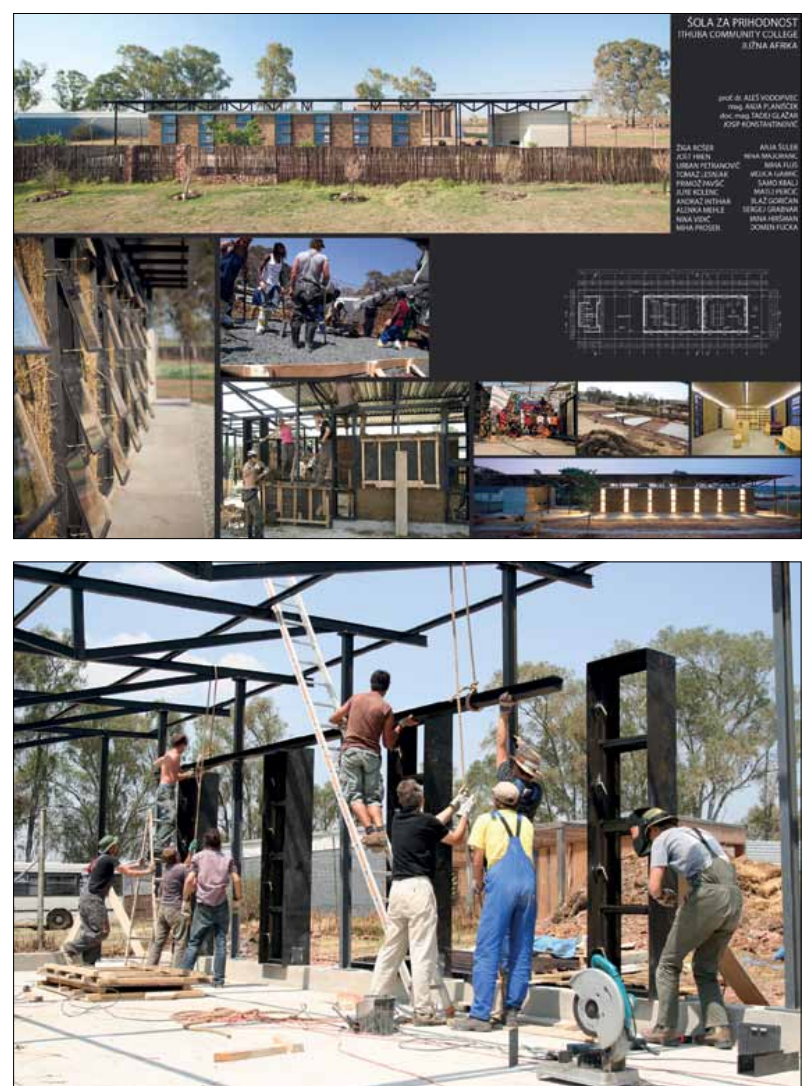

Fig. 1. A school for the future. Ithuba community college South Africa. Source: Vodopivec et al. 2011. 

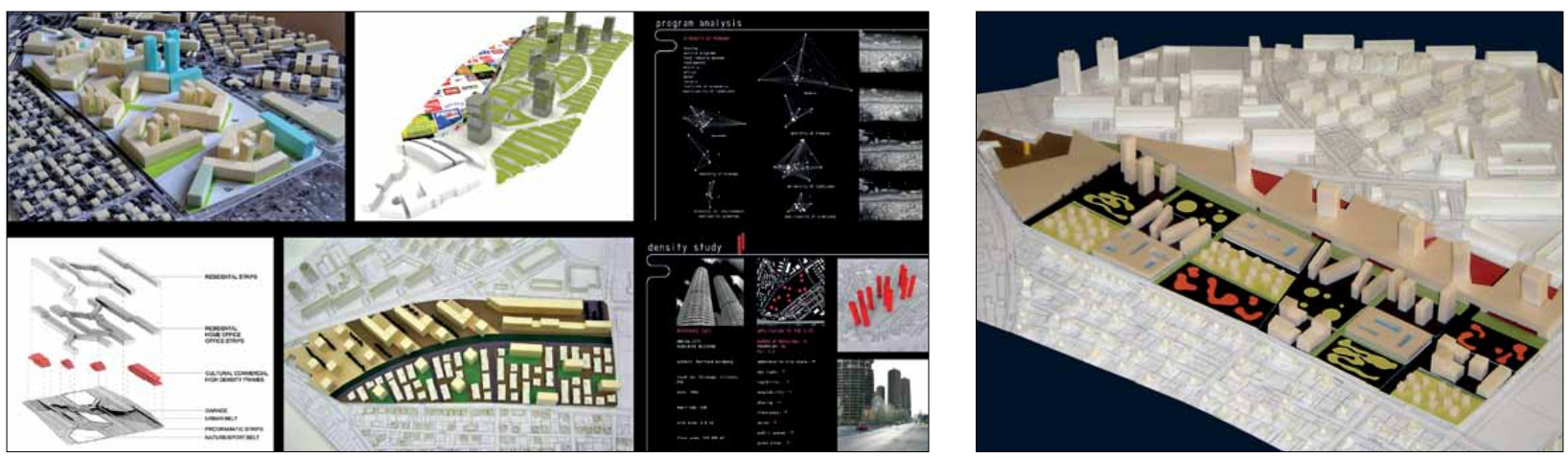

Fig. 2. Modelling and searching of different ideas and visions. Source: Gabrijelčič, Fikfak (2012).

The first part of the workshop focused on the elaboration of different development scenarios related to the programme and spatial planning of the Šmartinska Street corridor (Fig. 2). The second part addressed the problem of transport and architectural design of the new city boulevard with a link to the east motorway. The mentors, i.e. professionals (project team leaders), and the students prepared four development scenarios. These were professionally elaborated using different methods, such as: projections, location theories, models and simulations of urban development, drawing up scenarios, urban games, SWOT analyses, Delphi method, brainstorming, roundtables etc.

The results of the workshop comprised a textual representation of the problem, description of the concept and graphic representation with relevant mapping. The work covered interdisciplinary aspects that were topically connected with the fields of spatial planning, transport, urban planning and architecture. Based on the conclusions of the international student workshop, an international competition entitled "Partnership Šmartinska" was announced in 2008.

\section{Awarded master work}

The graduation work "Study of urban design of densification and gentrification of a residential neighbourhood - the case of Galjevica in Ljubljana" (Kušar 2012; see Fig. 3) is a result of architectural and urban design creativity. The paper is a mix of understanding and elaboration of the problems of different areas, including technical knowledge and knowledge of fine arts and aesthetics. The author's work is versatile and opens knowledge in different work areas: sociological, economic and spatial rules of the investigated area, connecting the said problems in a model of densification of freestanding single-apartment units with an accessible price range. The multi-layered thinking about the interventions into the built environment follows the principle: How should the symbiosis of benefits of the existing and new inhabitants work?
Based on the set goals, the executed cases help to design a model of densification that is adapted to Slovenia. The review of a simple theoretical spatial model was followed by a workshop simulating the planning process, in the framework of organized work with the inhabitants of a chosen street in Ljubljana. The urban and architectural concept of densification with wooden prefabricated modular units (Modeko system) follows the basic concept of street planning, in a way that it was designed by the participants at the workshop. Based on the architectural plans, a cost-effectiveness analysis was made.

The work was awarded the highest Slovenian university award, i.e. The Prešeren Award of the University of Ljubljana for students for 2011/2012. The work was
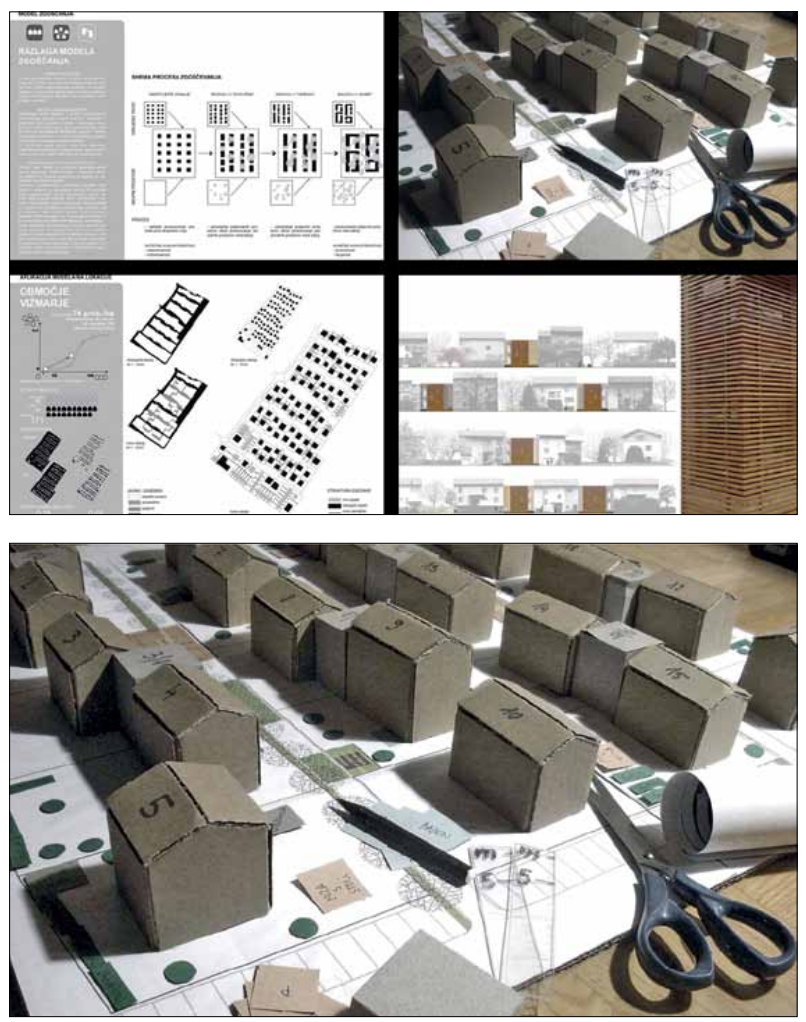

Fig. 3. Symbiosis of existing and new inhabitants. Source: Kušar (2012). 
also presented at a scientific conference "Smart urban planning: innovative approaches to urban planning and design", on 14 June 2012 at the UL FA.

\section{Installations at the FA halls}

Creativity is considered more important than productivity, whereby the latter is the result of the former (Mulej et al. 1994). It is often confused with originality, which is not the same, nevertheless, it is its constituent part, (...) however, creative things are more than just original (...) (Guštin 2007). Creative and experiential learning and work help us to build values, skills and knowledge with everyday work and social experiences. Independent and creative experimental research work, intertwined with experience, is irreplaceably complementing complex and/or general knowledge.

Here, three "creative" experiences are briefly presented (Fig. 4). The first part of each workshop ${ }^{8}$ was carried out in the form of an interactive information exchange via a social network, i.e. by e-mails between the students and the mentors. Initial preparations asked for an active collection and consideration of information, and an opinion about the information. In order to realize the idea of spatial composition, the key issue was to find the appropriate place (FA premises) and time (limitation to three days of active work). An additional restriction was manual work without the use of a computer, and minimum costs with the possibility of recycling the material already used.
Workshop 1 (December 2010): material - Kappa foam board; triangle as the chosen shape; review of stacking basic, unequal shapes; jointing triangles and checking of shape properties; mounting of a spatial installation at the FA corridor; lighting; 3D composition.

Workshop 2 (March 2011): material - old advertising material; folding paper into tubes, stacking of shapes and/or clipping the tubes into a surface, the basic module; elaboration of a 3D composition of a room; finalisation of the "leisure room"; its lighting, finishing and chair design as an element for observation of the paper structure.

Workshop 3 (April 2013): material - white plastic cups; clipping of elements into curves; stacking and folding of surfaces into a composition; making a 3D composition of a room; finalising the composition of a "leisure room"; shaping the ambient and the individual elements, circle, observation of structure.

The strengths of such an approach to work are two-fold. Firstly, they are related to the teaching and learning process that connects all participants into an interactive group of cooperation, dialogue and work, culminating in a spatial installation. Such teaching and learning approach is already part of the curricula of some courses; however, the implementation varies depending on the problem and goals set. Secondly, the strengths relate to the goals of the teaching process, i.e. trying to familiarize the students with new materials, their properties and possibilities at hand.
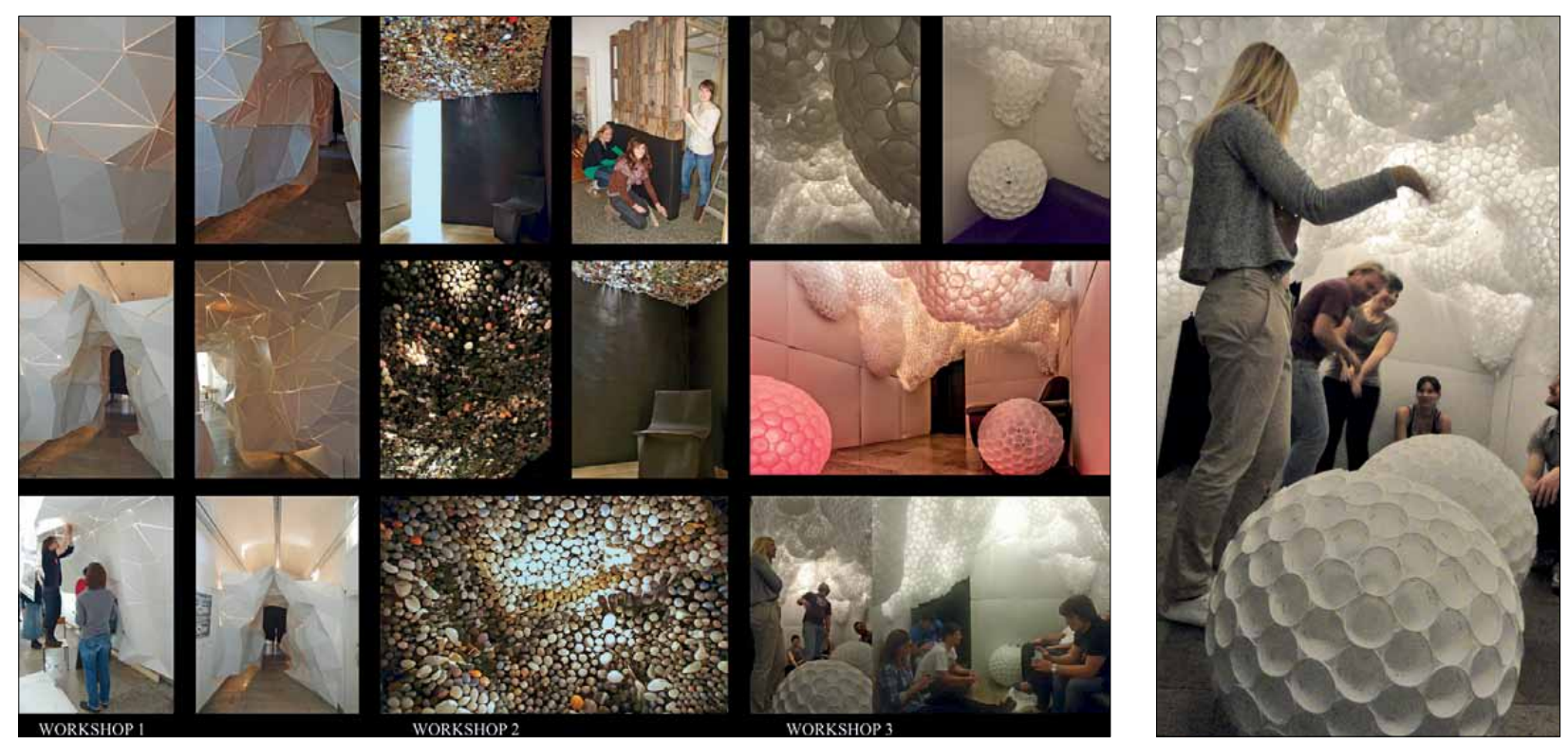

Fig. 4. Final model: Elements, materials and shapes - shaping the ambient. Source: Fikfak (2010, 2011, 2013); photo: workshop participants.

\footnotetext{
8 These spatial planning workshops involve activities that build on enthusiasm, free selection and volunteerism which go beyond profession and are unpaid, which is without doubt /.../ the underlying modern format of personal solidarity of social commitment in any environment (Frkač 1996: 335), including the academic one.
} 


\section{Conclusions}

In the first stage of reorganising the FA study programme of architecture into MSPA, using the "standardised" format, the unwanted effects of the Bologna reform have put the stability of the study programme at risk, particularly due to the rigidity of the system and incapability of continuous introduction of change (as prescribed in Slovenia by SQAA). Finally, let me emphasise the relationship between the administrative effects of change (quality evaluation of the education and the Bologna system) and the delivery of the study programme as an interdisciplinary creativity. The latter effects, in particular, are not negative. On the contrary, the implementation of MSPA has proven that the interdisciplinary creativity is feasible despite the reform; we want to keep these approaches and upgrade them with even more up-to-date formats of the teaching process:

- The quality of architectural education is reflected in work outcomes that go beyond the indicators of quality. The cases described in section 'Case examples showing a direct connection between creative, experiential work and interdisciplinarity' support this assumption. In architectural education, the quality and commitment of the educator, mentor, work group and participating experts are of utmost importance; they are led by the desire to study the unseen, the unknown and the new. Looking at the quality assessment indicators (Table 1), we find that the study programme and institution do not offer the same aspect of creativity as the one created by individuals.

- Changes introduced under the Bologna system. In the university study programme of architecture at the UL FA before the Bologna reform, the connections between architecture, design and urban planning presented a great advantage. In MSPA, these connections have been reduced; they remain flexible only in the delivery of elective courses. At the UL FA, we are trying to preserve these subject matters by introducing a new education of urban planning and design (a new study programme) that would also include many contents included in the study programmes of architecture. This would recreate the integration of two types of spatial content that are, in fact, inseparable and complex each on its own, and thus necessary when creating a quality of living. The manner of delivery is important, as the fundamental courses, Design Studio and Arhitectural Workshop, are carried out in the same place as the Urban Design course, and include the principles of interdisciplinarity through group work and participatory learning.
- Creative learning. Creativity and experiential learning are inseparably linked, whereby the inclusion of the individual person into the experience, thinking and group cooperation is vital. Architectural workshops are the platform that opens new visions and exposes spatial and structural change (not only solutions); for the understanding of built and/or natural environments the right way of thinking and work process is necessary, i.e. as a by-product of experiential learning. Indeed, this form of work is necessary for development of understanding in students and teachers, and the dialogue among them (and within a group).

\section{References}

Bonča, J.; Fikfak, A.; Kušar, D. 2012. Poročilo samoevalvacijske komisije fakultete za arhitekturo o ukrepih samoevalvacije za obdobje 2007-2012. Ljubljana: Univerza v Ljubljani, Fakulteta za arhitekturo.

Communiqué of the Conference of Ministers responsible for Higher Education in Berlin 2003. Realising the European Higher Education Area [online], [cited 5 September 2013]. Available from Internet: http://www.ond.vlaanderen. be/hogeronderwijs/bologna/documents/MDC/Berlin_ Communiquel.pdf

Construction Products Directive (EU) No 89/106/EEC (CPD) [online], [cited 5 September 2013]. Available from Internet: http://ec.europa.eu/enterprise/sectors/construction/legislation/

Construction Products Regulation (EU) No 305/2011 (CPR) [online], [cited 5 September 2013]. Available from Internet: http://ec.europa.eu/enterprise/sectors/construction/ legislation/

Fikfak, A. 2010. Delavnica 1: Elementi, materiali in oblike. Ljubljana: Fakulteta za arhitekturo.

Fikfak, A. 2011. Delavnica 2: Elementi, materiali in oblike. Ljubljana: Fakulteta za arhitekturo.

Fikfak, A. 2013. Delavnica 3: Elementi, materiali in oblike. Ljubljana: Fakulteta za arhitekturo.

Frkač, J. 1996. Prostovoljno delo, Socialno delo 35(4): 335-340. Ljubljana: Fakulteta za socialno delo.

Gabrijelčič, P. 2010. Študentske urbanistično-arhitekturne delavnice, pomembno strokovno orodje pri iskanju prostorskih rešitev za urejanje mestnih jeder, Dialogi 46(7/8): 151-168. Maribor: Založba Aristej.

Gabrijelčič, P.; Fikfak, A. 2012. Igra ustvarjalnosti: urbanistične, urbanistično-arhitekturne in planerske delavnice. Ljubljana: Fakulteta za arhitekturo.

Guštin, N. 2007. Aktiviranje ustvarjalnosti za večjo inovativnost poslovanja podjetja [online], [cited 10 July 2013]. Magistrsko delo. Maribor: Univerza v Mariboru, Ekonomsko-poslovna fakulteta. Available from Internet: http://www.epf.uni-mb. si/ediplome/pdfs/gustin-natasa-mag.pdf

Ivanitskaya, L.; Clark, D.; Montgomery, G.; Primeau, R. 2002. Interdisciplinary learning: process and outcomes, Innovative Higher Education 27(2): 95-111 [online], [cited 10 January 2011]. Available from Internet: https://www. umaine.edu/sustainabilitysolutions/faculty_resources/pdfs/ Ivanitskaya.pdf 
Kušar, K. 2012. Študija urbanistične zasnove zgoščanja in gentrifikacije stanovanjske soseske na primeru Galjevica v Ljubljani. Diplomska naloga. Ljubljana: Fakulteta za arhitekturo.

Marentič Požarnik, B. 2010. Kakšno učenje, pouk, metode ... za uspešno uresničevanje ciljev okoljske vzgoje-vzgoje za trajnostni razvoj. Projekt Posodobitev gimnazije - posodobitev učnih načrtov. Operativni program razvoja človeških virov v obdobju 2007-2013, Razvojne prioritete: Razvoj človeških virov in vseživljenjsko učenje; prednostne usmeritve: Izboljšanje kakovosti in učinkovitosti sistemov izobraževanja in usposabljanja [online], [cited 28 July 2010]. Ministrstvo za šolstvo in šport. Ljubljana. Evropski socialni sklad. Bruselj. Available from Internet: http://www.zrss.si/

Mulej, M., et al. 1994. Inovacijski management. Knj. 1, Inoviranje managementa. Maribor: Ekonomsko-poslovna fakulteta.

Nakvis. 2010. Merila za akreditacijo in zunanjo evalvacijo visokošolskih zavodov in študijskih programov [Rules for accreditation and external evaluation of higher education institutions and study programs] [online], [cited 10 July 2013]. SQAA. Available from Internet: http://test.nakvis. si/sl-SI/Content/Details/2

Richardson, V.; Friend, A. 2006. How places work [online], [cited 14 April 2013]. Commission for Architecture and the Built Environment. Available from Internet: http://www. cabe.org.uk/

South Africa Ithuba Project [online], [cited 1 Septemer 2013]. Available from Internet: http://www.saip.si/

Širok, J.; Debevec, T. 2013. Priročnik za strokovnjake Nacionalne agencije Republike Slovenije za kakovost v visokem šolstvu [online], [cited 1 Septemer 2013]. Ljubljana: Nacionalna agencija Republike Slovenije za kakovost v visokem šolstvu. Available from Internet: http://test.nakvis.si/en-GB/ Content/Details/8

Univerza v Ljubljani [University of Ljubljana]. 2000. Navodila $z a$ ocenjevanje in zagotavljanje kakovosti na UL [Rules on assessment and quality assurance at the University of Ljubljana] [online], [cited 5 of September 2013]. Available from Internet: http://www.uni-lj.si/o_univerzi_v_ljubljani/ kijz.aspx

Univerza $v$ Ljubljani [University of Ljubljana] 2008. Pravila o sistemu spremljanja in zagotavljanja kakovosti UL [Rules on the system of quality monitoring and assurance of the University of Ljubljana] [online], [cited 5 of September 2013]. Available from Internet: http://www.uni-lj.si/o_univerzi_v_ljubljani/predpisi_statut_ul_in_pravilniki/kakovost.aspx

Vodopivec, A.; Gabrijelčič, P. (Eds.). 2013. Samoevalvacijsko poročilo [online], [cited 10 July 2013]. Ljubljana: Univerza v Ljubljani, Fakulteta za arhitekturo. Available from Internet: http://www.fa.uni-lj.si/default.asp?id=2354

Vodopivec, A.; Planišček, A.; Glažar, T.; Kostantinovič, J.; Skubic, B.; Intihar, A.; Kolenc, J.; Petranovič, U. 2011. School for the future: classroom and library, Ithuba Skills College, Johannesburg: South African Republic. Ljubljana: Fakulteta za arhitekturo.

Zavodnik Lamovšek, A.; Foški, M. 2012. The role of the interdisciplinary learning for the urban design and spatial planning workshop, in Gabrijelčič, P.; Fikfak, A. Igra ustvarjalnosti: urbanistične, urbanistično-arhitekturne in planerske delavnice. Ljubljana: Fakulteta za arhitekturo, 70-77.

\section{ALENKA FIKFAK}

Assistant Professor, Ph.D. Chair of Urbanism, Faculty of Architecture, University of Ljubljana, Zoisova 12, 1000 Ljubljana, Slovenia.E-mail: alenka.fikfak@fa.uni-lj.si

Research interests: spatial and landscape planning, planning of small settlements, ruralism and rural architecture, regulatory plans for the regulation of non-urban settlements, evolutionary constants of a settlement culture undergoing renovation, with particular reference to the coastal region, models for revitalisation of degraded landscape areas, analysis of trends of spatial development. Interreg IIIA Italia - Slovenia 2000-2006, "Sustainable settlement models and typologies for transborder territories" (2004). Project ALPTER - "Terraced landscapes of the alpine arc" EU Programme Interreg IIIB Alpine Space (2005-2006). Project Cultura 2000 "Virtual museum of the European Transhumance" (2006-2007). Project TIGR "Sustainable and Innovative Civil Engineering: the Development of the Building Concept" (2011-2013). Project Atrium "Architecture of Totalitarian Regimes of the XXth Century in Urban Management" (2011-2013), Project Tempus "Restructuring of Study Programme in Architecture to Long-Cycle Integrated Master in Line with EU Standards" (2012-2015), project Espon Train "Establishment of Transnational Espon Trainning Programme to Stimualte Interests to Espon 2013 Knowledge" (2011-2013).

Giving lessons: Compulsory subject - assistant tutor at Design Studio I, II, III, IV and V. Also tutor for numerous domestic and international workshops and Summer schools in each year. Compulsory subject (assistant): Rurism and rural architecture. Elective subject (assistant): Landscape architecture and environment preservation. In more than 15 years worked as assistant tutor with students of Faculty of Architecture (University of Ljubljana), and from 2005 with Erasmus students from Spain, Portugal, Belgium, Slovakia, Italy, ... Since 1999 co-mentored more than 50 graduation works of students. Organised more than 10 architectural and urbanistical workshops (presentations of the work and exhibitions) for different local communities in Slovenia - population of the students work on the local level. Co-organised International conference of Spatial Planning development: From the urban plan to the regulations of settlements, 1999; Theory and chritics in Architecture: 60 architectural reviews in Eurpoe, 2001 (both on Faculty for Architecture). 